\title{
The Contribution of Serotonergic Receptors and Nitric Oxide Systems in the Analgesic Effect of Acetaminophen: An Overview of the Last Decade
}

\author{
Asetaminofenin Analjezik Etkisinde Serotonerjik Reseptörlerin ve Nitrik \\ Oksit Sisteminin Katkısı: Son On Yıla Genel Bakış
}

\author{
(D) Yeșim HAMURTEKIN, (D) Ammar NOUILATI, (D) Cansu DEMIRBATIR, (D) Emre HAMURTEKIN* \\ Eastern Mediterranean University, Faculty of Pharmacy, Department of Pharmacology, Famagusta, North Cyprus Via Mersin 10, Turkey
}

\begin{abstract}
Acetaminophen is a widely used analgesic and antipyretic agent. It is also available in over the counter formulations, which has increased its wide use. There have been many studies to date that have aimed to evaluate the mechanism of the analgesic action of acetaminophen. Additional to the inhibition of the cyclooxygenase pathway in the central nervous system, the involvement of opioidergic, cannabinoidergic, dopaminergic, cholinergic, and nitrergic systems as well as the contribution of descending pain inhibitory systems like the bulbospinal serotonergic pathway has been proposed as possible mechanisms of the analgesic action of acetaminophen. In this review, we aimed to collect the data from studies revealing the contribution of the central serotonergic system and the role of central nervous system-located serotonergic receptor subtypes in the analgesic effect of acetaminophen. While doing this, we mainly focused on the research that has been performed in the last ten years and tried to link the previous data with the lately added results. In addition to serotonergic system involvement, we also reviewed the role of nitric oxide in the analgesic action of acetaminophen, especially with the new findings reported over the last decade.
\end{abstract}

Key words: Acetaminophen, serotonin, pain, nitric oxide

Öz

Asetaminofen yaygın kullanılan analjezik ve antipiretik bir ajandır. Reçetesiz verilebilen formülasyonlarının da mevcudiyeti sık kullanımını artırmıştır. Günümüze kadar asetaminofenin analjezik etki mekanizmasını inceleyen bir çok çalıșma bulunmaktadır. Santral sinir sisteminde siklooksijenaz yolağını inhibe etmesinin yanında, opioiderjik, kannabinoiderjik, dopaminerjik, kolinerjik ve nitrerjik sistemler kadar, bulbospinal serotonerjik yolaklar gibi analjezik etkili inen inhibitör yolakların da asetaminofenin analjezik etkisinde katkısı olan olası mekanizmalar olduğu önerilmiştir. Bu derlemede santral serotonerjik sistem ve santral sinir sistemindeki serotonerjik reseptör alt tiplerinin parasetamolün analjezik etkisine katkısını ortaya koyan verileri bir araya getirmeyi amaçladık. Bunu yaparken, esas olarak son on yılda yapılmış çalışmalara odaklandık ve önceki verilerle son eklenenler arasında bir bağlantı kurmaya çalıştık. Serotonerjik sistemin katkısına ek olarak, aynı zamanda son on yıldaki yeni bulgularla asetaminofenin ağıı kesici etkisinde nitrik oksidin rolünü de derledik.

Anahtar kelimeler: Asetaminofen, serotonin, ağrı, nitrik oksit

\section{INTRODUCTION}

Although acetaminophen is one of the most commonly used medications, its exact analgesic mechanism of action is still a mystery. Not only has decreased prostaglandin production via cyclooxygenase (COX) enzyme inhibition (especially COX-2, and a central splice variant of COX-1, which is COX-3) been proposed as the primary mechanism of analgesic action, ${ }^{1-3}$ but also the contribution of cannabinoidergic ${ }^{4}$ and opioidergic ${ }^{5}$ systems has been shown. In addition to these main contributions, cholinergic ${ }^{6}$ and dopaminergic ${ }^{7}$ systems have also been shown to be involved in acetaminophen analgesia. Not only the above neuronal systems, but also the role of calcium channels (T-type voltagegated calcium channels) has been proposed to be involved in the analgesic effect of acetaminophen. ${ }^{8}$

The aim of this review is to discuss the two other proposed mechanisms for the analgesic action of acetaminophen, namely the serotonergic system with its various receptor subtypes and nitric oxide (NO) systems. It is focused on the findings in the last decade regarding the contribution of these two systems in acetaminophen analgesia with the intention of comparing these

*Correspondence: E-mail: emre.hamurtekin@emu.edu.tr, Phone: +90 392630 2449 ORCID-ID: orcid.org/0000-0001-8305-9283 
new findings with the previous results and combining these novel findings.

The role of the central serotonergic system in acetaminophen analgesia

In 1991, the antinociceptive effect of acetaminophen in a formalin test was reduced following the chemical impairment of spinal serotonergic pathways (bulbospinal serotonergic pathway) by intrathecal 5,6-dihydroxytryptamine (5,6-DHT) administration in rats. That study indicated the contribution of the spinal serotonergic system in the analgesic action of acetaminophen. ${ }^{9}$ This was followed by the finding that the antinociceptive effect of systemic acetaminophen administration to rats was reduced by the administration of $p$-chlorophenylalanine, which was known to deplete the brain's serotonin levels. Additionally, acetaminophen increased serotonin levels in the brain cortex and pons. As a result, these findings showed the involvement of the supra-spinal serotonergic system in acetaminophen analgesia. ${ }^{10}$

These previous results have been confirmed and also expanded with some additional studies performed in the last decade. In animal studies, central serotonergic system impairment with intrathecal and intracerebroventricular 5,7-DHT administration and assessment of brain serotonin levels were the most commonly used methods. These methods enabled the evaluation of serotonergic system involvement in acetaminophen analgesia. Among these studies, some differences were observed in the effects of chemical destruction of the central serotonergic system on the analgesic effect of acetaminophen between different animal pain models and doses of acetaminophen. Recent results are summarized in Table 1.

Acetaminophen-induced serotonin increases have also been confirmed in recent studies. Intraperitoneal acetaminophen administration (400 mg/kg) induced approximately $40 \%$ and $75 \%$ increases in serotonin levels in the pons and frontal cortex, respectively. These increases in serotonin levels have been found to be related to central (hydroxytryptamine) $5-\mathrm{HT}_{2}$ receptors as well as opioid receptors $\left(\mu_{1}\right.$ and $\left.\kappa\right) .^{5}$ These data were confirmed in a study by Vijayakaran et al. ${ }^{14}$ in which acetaminophen ( $400 \mathrm{mg} / \mathrm{kg}$; oral) caused increases in serotonin levels in the rat frontal cortex and brain stem. Serotonin increases were observed not only following acute applications but also following chronic acetaminophen applications. Subcutaneous acetaminophen in 10 and $50 \mathrm{mg} / \mathrm{kg}$ doses was administered to 3-month-old rats and serotonin levels in the prefrontal cortex, hippocampus, hypothalamus, and striatum were analyzed. Serotonin levels increased after the $10 \mathrm{mg} /$ $\mathrm{kg}$ acetaminophen dose (not with $50 \mathrm{mg} / \mathrm{kg}$ ) in the prefrontal cortex but not in the other brain regions analyzed in this study. Additionally, 5-HIAA levels decreased in the hypothalamus and striatum. ${ }^{15}$ All these recent studies have confirmed the idea that systemic acetaminophen administration increases serotonin levels in the brain cortex and brain stem (pons) and meet at a common point, which is that acute and chronic systemic administration of acetaminophen induces changes in central serotonergic neurotransmission. It can be concluded that, despite the involvement of $5-\mathrm{HT}_{2}$-serotonergic and opioid receptors in acetaminophen-induced serotonin increases in some brain regions, ${ }^{5}$ apparently the exact mechanism (alterations in serotonin metabolism, release, or uptake) is still not clear and needs to be clarified.

The signs of serotonergic involvement in acetaminopheninduced analgesia in humans were also studied. However, despite some supportive results, serotonergic contribution seems still doubtful in human studies due to the challenges in studying pain in humans. Controversial data have been observed between the results in healthy volunteers and patients with pain. ${ }^{16}$ The findings of these studies will be discussed in the following sections.

\section{Some metabolites of acetaminophen and the central serotonergic system}

Acetaminophen, following its systemic administration, has been shown to be biotransformed to an amine compound, p-aminophenol, which occurs mainly in the liver. Enzymatic conversion of $p$-aminophenol to $\mathrm{N}$-arachidonoyl-phenolamine

Table 1. Effect of the deterioration of the bulbospinal serotonergic pathway with 5,7-dihydroxytryptamine (5,7 DHT) in the antinociceptive effect of acetaminophen in different pain models in some studies performed in the last decade

\begin{tabular}{|c|c|c|c|c|c|}
\hline 5,7-DHT & Acetaminophen & Pain model & Effect & Animal & References \\
\hline $100 \mu g$; i.t. & 3 mg/kg; i.p. & Paw pressure test & decrease & Rat (Sprague Dawley) & 11 \\
\hline $50 \mu g$; i.t. & $200-600 \mathrm{mg} / \mathrm{kg}$ & Tail flick test & decrease & Mouse (BALB/c) & 12 \\
\hline $50 \mu g$; i.t. & $200-600 \mathrm{mg} / \mathrm{kg}$ & Hot plate test & decrease & Mouse (BALB/c) & 12 \\
\hline $50 \mu g$; i.t. & $200-600 \mathrm{mg} / \mathrm{kg}$ & Plantar incision (thermal hyperalgesia) & decrease & Mouse (BALB/c) & 12 \\
\hline $70 \mu$ g; i.c.v. (neonatal age) & 100 mg/kg; oral & Writhing test & decrease* $^{*}$ & Adult rat (Wistar) & 13 \\
\hline $70 \mu$ g; i.c.v. (neonatal age) & 100 mg/kg; oral & Tail immersion & no change & Adult rat (Wistar) & 13 \\
\hline 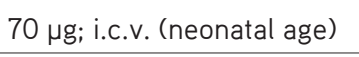 & 100 mg/kg; oral & Paw pressure test & no change & Adult rat (Wistar) & 13 \\
\hline 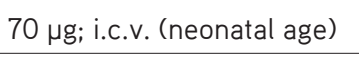 & 100 mg/kg; oral & Formalin test & no change & Adult rat (Wistar) & 13 \\
\hline
\end{tabular}

*Decrease in the hot plate test was more obvious than the decrease in the writhing test, i.t.: Intrathecal, i.c.v.: Intracerebroventricular, DHT: Dihydroxytryp tamine 
(AM404), which is catalyzed by fatty acid amide hydrolase (FAAH) enzyme with the conjugation of arachidonic acid, occurs in the brain, spinal cord, and dorsal root ganglia.. AM404 metabolite of acetaminophen has been shown to activate TRPV1 (transient receptor potential vanilloid-1, capsaicin receptor) channels and act as a CB1 (cannabinoid receptor type-1) ligand. ${ }^{17,18}$ Mallet et al.1 showed that CB1 receptors are vital for the analgesic action of orally administered acetaminophen, because CB1 receptor antagonism as well as gene deletion totally inhibited the analgesic action of acetaminophen in various pain models, i.e. thermal, mechanical, and chemical (formalin) painful stimuli in rats. CB1 receptor related activation of the descending serotonergic pathway has been suggested as the following step, because the antinociceptive effect of systemic acetaminophen was negated following the chemical impairment of the spinal serotonergic pathway. As a CB1 receptor ligand, AM404 metabolite of acetaminophen has been claimed to be responsible for this action. Spinal $5 \mathrm{HT}_{1 \mathrm{~A}}$ and $5 \mathrm{HT}_{3 / 4}$ receptors have been shown to contribute at the spinal cord level to the analgesic action of acetaminophen eventually. On the other hand, Ruggieri et al..$^{5}$ claimed that AM404 can only partially contribute to the analgesic action of systemically administered acetaminophen, depending on the fact that the observed analgesic action of AM404 was approximately half of the analgesic action of acetaminophen. This AM404 contribution seems to be related to the central $5 \mathrm{HT}_{3}$ receptors, but not to $5 \mathrm{HT}_{1 \mathrm{~A}}$ or $5 \mathrm{HT}_{2}$ receptor subtypes. Interestingly, a central $5 \mathrm{HT}_{2}$ receptor subtype, but not $5 \mathrm{HT}_{3}$ or $5 \mathrm{HT}_{1 \mathrm{~A}}$, has been found to be involved in the analgesic action of acetaminophen depending on the dose-dependent inhibition of acetaminophen's analgesic action with systemic ketanserin. Another important finding of their study was the increase in serotonin levels in the pons and frontal cortex following the administration of acetaminophen, but not with AM404. All these results of this study pointed out that acetaminophen and its metabolite AM404 have both analgesic actions but the mechanisms that play a role in this analgesic action differ between these two compounds. These differences regarding the contribution of AM404 to acetaminophen analgesia and the involvement of different serotonergic receptor subtypes may be related to the use of different types and different administration routes of serotonergic receptor subtype antagonists as well as the dose of acetaminophen, which was different in the two studies.

Finally, Barrière et al. ${ }^{19}$ showed the contribution of a descending serotonergic antinociceptive pathway in the analgesic effect of 4-aminophenol, another metabolite of acetaminophen as mentioned above. The analgesic effect of intraperitoneally administered 4-aminophenol was reported to depend on AM404 formation in the brain, which is catalyzed by FAAH enzyme, and TRPV1 and CB1 receptor stimulation-induced descending antinociceptive serotonergic system activation and spinal $5-\mathrm{HT}_{3}$ and $5-\mathrm{HT}_{1 \mathrm{~A}}$ serotonergic receptor subtypes were claimed to play an important role.

As a result, studies showed that not only acetaminophen itself but also its metabolites like AM404 and 4-aminophenol may play an important role in the analgesic action of acetaminophen.
It can be concluded that AM404 metabolite contributes to the analgesic action of systemic acetaminophen to some extent and activates the descending serotonergic antinociceptive pathway via the contribution of central TRPV1 and CB1 receptors. Spinal serotonergic receptor subtypes eventually play a role in the antinociceptive action, which may act differently to acetaminophen and its metabolites.

\section{Role of $5-H T_{1}$ receptors}

It is known that 5- $\mathrm{HT}_{1 \mathrm{~A}}$ and $5-\mathrm{HT}_{1 \mathrm{~B}}$ serotonergic receptor subtypes are largely located at the supra-spinal level: $5-\mathrm{HT}_{1 \mathrm{~A}}$ on the cell bodies and dendrites of serotonergic neurons and 5- $\mathrm{HT}_{1 \mathrm{~B}}$ mainly on the axon terminals. Both $5-\mathrm{HT}_{1 \mathrm{~A}}$ and $5-\mathrm{HT}_{1 \mathrm{~B}}$ serotonergic receptor subtypes have important effects on extracellular serotonin levels via modulation of nerve firing mainly for $5-\mathrm{HT}_{1 \mathrm{~A}}$ receptors and by modification of serotonin release for mainly $5-\mathrm{HT}_{1 \mathrm{~B}}$ serotonergic receptor subtypes. ${ }^{20}$ Blockade of $5-\mathrm{HT}_{1 \mathrm{~A}}$ receptor subtypes has been shown to enhance the extracellular levels of serotonin. ${ }^{21}$ Involvement of $5-\mathrm{HT}_{1}$ serotonergic receptor subtypes in the analgesic effect of acetaminophen has been studied in various studies with different animal pain models and with different ligands for $5-\mathrm{HT}_{1 \mathrm{~A}}$ and $5-\mathrm{HT}_{1 \mathrm{~B}}$ receptor subtypes. Incompatible results were obtained in earlier studies regarding the contribution of $5-\mathrm{HT}_{1}$ serotonergic receptors in the analgesic effect of acetaminophen. An earlier study showed that pre-administered WAY-100635 $\left(5 \mathrm{HT}_{1 \mathrm{~A}}\right.$ receptor antagonist, $10 \mu \mathrm{g} / \mathrm{rat}$; intrathecal) did not change the analgesic effect of intravenous acetaminophen $(200 \mathrm{mg} / \mathrm{kg})$ in a rat paw pressure test. ${ }^{22}$ However; intrathecal administration of WAY-100635 (40 $\mu \mathrm{g} / \mathrm{rat}$ ) has been shown to block acetaminophen analgesia (3 $\mathrm{mg} / \mathrm{kg}$, i.p.) in both phase I and II of a rat formalin test..1 In addition, intraperitoneal administration of NAN-190 (5-HT, serotonergic receptor antagonist, $1-5 \mathrm{mg} / \mathrm{kg}$ ) did not change the acetaminophen analgesia in hot plate or paw pressure tests and did not show any blockage of acetaminophen-induced serotonin increases in the frontal cortex and pons. ${ }^{5}$ However, it should not be underestimated that NAN-190 could also block the $\alpha_{2}$-adrenergic receptors and this finding can raise some suspicions regarding NAN-190 when using it as a specific $5-\mathrm{HT}_{1 \mathrm{~A}}$ receptor antagonist. ${ }^{23}$ Interestingly, another earlier study showed that systemic administration of $5-\mathrm{HT}_{1 \mathrm{~A}}$ and $5-\mathrm{HT}_{1 \mathrm{~B}}$ receptor antagonists enhanced the acetaminophen analgesic action, whereas stimulation of the same receptor subtypes blocked the acetaminophen analgesia in a hot plate test. ${ }^{24}$ This was in close agreement with the findings reported by Sandrini et al. ${ }^{25}$ in which systemic administration of CP $93129\left(5-\mathrm{HT}_{1 \mathrm{~B}}\right.$ receptor agonist) prevented acetaminophen analgesia in hot plate and paw pressure tests. These two findings suggested that increased serotonin release and/or enhanced firing of serotonergic nerves, which liberate themselves from the suppressing effects of $5-\mathrm{HT}_{1 \mathrm{~A}}$ and $5-\mathrm{HT}_{1 \mathrm{~B}}$ receptors, augment the antinociceptive action of acetaminophen. The findings of a recent study also were in good accordance with those previous results. Oral buspirone as a $5 \mathrm{HT}_{1}$ serotonergic receptor agonist blocked the antinociceptive action of intraperitoneal acetaminophen $(200 \mathrm{mg} / \mathrm{kg})$ in a hot plate test and in the early phase of a formalin test in mice. ${ }^{26}$ 
As a result, when taken together it can be concluded that despite some negative results $5-\mathrm{HT}_{1 \mathrm{~A}}$ and $5-\mathrm{HT}_{1 \mathrm{~B}}$ serotonergic receptor subtypes are likely to contribute to acetaminophen analgesia. However, characteristics of this contribution seem to depend on the ligands and animal pain models tested as well as the location (spinal/supra-spinal or presynaptic/postsynaptic) of 5-HT, serotonergic receptors and still needs to be evaluated.

\section{Role of 5-HT, receptors}

The possible involvement of $5-\mathrm{HT}_{2}$ serotonergic receptor subtypes in the analgesic effect of acetaminophen has also been examined in recent studies. Ruggieri et al. ${ }^{5}$ showed a statistically significant reduction in the antinociceptive action of acetaminophen when ketanserin ( $5 \mathrm{mg} / \mathrm{kg}$; subcutaneous) was administered systemically before acetaminophen $(400 \mathrm{mg} / \mathrm{kg}$; intraperitoneal), whereas it did not change the antinociceptive effect of AM404 in hot plate and paw pressure tests. In another study, Dogrul et al. ${ }^{12}$ showed that intrathecally administered ketanserin $(10 \mu \mathrm{g})$ did not change the antinociceptive effect of acetaminophen $(200-600 \mathrm{mg} / \mathrm{kg}$; oral) in hot plate or tail flick tests or in thermal hyperalgesia after incision of the hind paw. This recent study seems to reveal findings opposite those from the study by Courade et al. ${ }^{22}$ due to the fact that intrathecally administered ketanserin (5- $\mathrm{HT}_{2 \mathrm{~A}}$ antagonist) as well as mesulergine $\left(5-\mathrm{HT}_{2 \mathrm{C}}\right.$ antagonist) decreased vocalization thresholds, which had been increased by intravenously administered propacetamol (water soluble prodrug form of acetaminophen). The differences in the study designs, like the animals (mice/rat), the animal pain models (tail flick-hot plate/ paw pressure test) that were used, and the timing of ketamine administration (before or after acetaminophen), between these two studies should be considered. Even so, when these studies are considered together, although the involvement of spinally located $5-\mathrm{HT}_{2}$ receptors in acetaminophen analgesia needs to be elucidated, it can be speculated that supra-spinal $5-\mathrm{HT}_{2}$ serotonergic receptors may contribute to the analgesic effects of acetaminophen. Additionally, $5-\mathrm{HT}_{2}$ receptors are likely to be involved in the antinociceptive effect of acetaminophen, not in the antinociceptive effect of its metabolite, AM404. Supporting this assumption, systemic ketanserin has also been shown to block acetaminophen-induced serotonin increases in the frontal cortex and pons. ${ }^{5}$ Acetaminophen administration has also been shown to increase the serotonin levels in supraspinal structures and led to a down-regulation of $5-\mathrm{HT}_{2 \mathrm{~A}}$ receptor subtypes in the frontal cortex and brain stem. ${ }^{14}$ In that study, the authors stated that an increase in serotonin release triggered by acetaminophen caused down-regulation of $5-\mathrm{HT}_{2 \mathrm{~A}}$ receptors related to the long duration of stimulus by serotonin. This assertion was supported by the study by Srikiatkhachorn et al. ${ }^{27}$ claiming that $5-\mathrm{HT}_{2 \mathrm{~A}}$ receptor down-regulation is important for the analgesic effect of acetaminophen. Thus, it may be speculated that supra-spinal located (most likely postsynaptic) $5-\mathrm{HT}_{2}$ receptor stimulation by serotonin, which is enhanced following acetaminophen administration, contributes to the analgesic action of acetaminophen. Recent results are summarized in Table 2.

\section{Role of $5-\mathrm{HT}_{3}$ receptors}

The contribution of $5-\mathrm{HT}_{3}$ receptors in the analgesic effect of acetaminophen has been tested in various animal pain models as well as in human studies. Different $5-\mathrm{HT}_{3}$ receptor antagonists, like granisetron, ondansetron, and tropisetron, have been used to study the interaction of these receptor subtypes in acetaminophen analgesia. In 1996, the indirect contribution of spinal $5-\mathrm{HT}_{3}$ serotonergic receptor subtypes was pointed out based on the findings of research. In that research, it was shown that spinal tropisetron totally inhibited the antinociceptive action of systemically and spinally administered acetaminophen in a rat paw pressure test. ${ }^{28}$ This finding had also been confirmed in inflammatory pain models. ${ }^{29}$ In the last decade, a study by Mallet et al." showed that intrathecal application of $0.5 \mu \mathrm{g}$ of tropisetron pre-treatment blocked the increased vocalization thresholds by systemic administration of acetaminophen, which was in good accordance with the previous findings. However, studies with the other tested $5-\mathrm{HT}_{3}$ receptor antagonists revealed mostly opposite results. Ondansetron administration (systemic as well as intrathecal) was shown not to alter the analgesic effect of acetaminophen significantly. ${ }^{25,30}$ Recent studies also confirmed this finding. Systemic ondansetron pretreatment $(2 \mathrm{mg} / \mathrm{kg}$; subcutaneous) did not alter the effect of acetaminophen in hot plate or paw pressure tests in rats, ${ }^{5}$ in good accordance with the finding that spinally administered ondansetron caused no change in the effect of orally administered acetaminopheninduced analgesia in hot plate or tail flick tests or in thermal hyperalgesia in a plantar-incision model..$^{12}$ An exception is a study in which acetaminophen-induced analgesia was blocked by ondansetron in a mouse formalin test. ${ }^{31}$ Among these studies, differential involvement of $5-\mathrm{HT}_{3}$ receptors in acetaminophen and AM404-induced analgesia (similar to ketanserin) has been shown in which ondansetron administration was able to block the analgesic effect of AM404. ${ }^{5}$ Another $5-\mathrm{HT}_{3}$ receptor antagonist, granisetron, caused no significant changes in the analgesic effect of acetaminophen in a paw pressure test. ${ }^{22,30}$ As a result, when the animal studies over the last ten years are considered together with the previous data, we can conclude that administration of ondansetron and granisetron is not likely to alter the effect of acetaminophen-induced analgesia, whereas tropisetron inhibits the analgesic effect of acetaminophen in various animal pain models. These different contributions can be explained by the differences between these antagonists regarding their pharmacokinetical properties (especially primary responsible cytochrome p450 system in the liver for their metabolism), $5-\mathrm{HT}_{3}$ receptor binding affinities, selectivity and specificity on $5-\mathrm{HT}_{3}$ receptors, and their duration of action. ${ }^{32,33}$ However, another issue raised at this point was the examination of $5-\mathrm{HT}_{3}$ receptor subtype contribution in the interaction between tropisetron- and acetaminophen-induced analgesia due to the finding that acetaminophen analgesia was not altered by other $5-\mathrm{HT}_{3}$ receptor antagonists like ondansetron and granisetron. Additionally, spinal $5-\mathrm{HT}_{3}$ receptor antisense oligodeoxynucleotide pre-treatment, which aimed to decrease the synthesis of $5-\mathrm{HT}_{3}$ receptors, did not inhibit the antinociceptive action of acetaminophen.$^{30}$ As a result, it 
Table 2. Some studies on the effect on the role of $5-\mathrm{HT}_{2}$ receptors on the analgesic effect of acetaminophen in different pain models

\begin{tabular}{|c|c|c|c|c|c|}
\hline Acetaminophen & $5-\mathrm{HT}_{2}$ antagonist & Animal & Pain model & $\begin{array}{l}\text { Effect on acetaminophen } \\
\text { analgesia }\end{array}$ & Reference \\
\hline $200 \mathrm{mg} / \mathrm{kg}$, i.v. & $\begin{array}{l}\text { Ketanserin \& mesulergine } \\
(10 \mu g, \text { i.t. })-5 \text { min before acetaminophen }\end{array}$ & Rat & Paw pressure & Decrease & 22 \\
\hline 400 mg/kg, i.p. & Ketanserin (5 mg/kg, s.c.) & Rat & Hot plate & Decrease & 5 \\
\hline 400 mg/kg, i.p. & Ketanserin $(5 \mathrm{mg} / \mathrm{kg}$, s.c.) & Rat & Paw pressure & Decrease & 5 \\
\hline $200-600 \mathrm{mg} / \mathrm{kg}$, oral & Ketanserin $(10 \mu g$, i.t. $)-60$ min after acetaminophen & Mice & Tail flick test & No effect & 12 \\
\hline $200-600 \mathrm{mg} / \mathrm{kg}$, oral & Ketanserin $(10 \mu g$, i.t.)- 60 min after acetaminophen & Mice & Hot plate & No effect & 12 \\
\hline $200-600 \mathrm{mg} / \mathrm{kg}$, oral & Ketanserin $(10 \mu g$, i.t.)- 60 min after acetaminophen & Mice & Post-incision & No effect & 12 \\
\hline
\end{tabular}

i.v.: Intravenous, i.p.: Intraperitoneal, s.c.: Subcutaneous, i.t.: Intrathecal

has been started to be speculated that not the spinal 5-HT3 receptor subtypes but another tropisetron-sensitive receptor may play a role in the analgesic action of acetaminophen. ${ }^{30}$ Additionally, it has been indicated that tropisetron can also show affinity to other receptors like $\alpha 7$-nicotinic receptor subtypes..$^{30,34}$ When all these are considered together, the role of central 5-HT3 serotonergic receptors in the analgesic effect of acetaminophen seems to be clarified with further studies.

The contribution of $5-\mathrm{HT}_{3}$ receptors in the analgesic effect of acetaminophen has also been studied in humans using tropisetron, granisetron, and ondansetron. These studies had two important goals: to reveal the involvement of $5-\mathrm{HT}_{3}$ serotonergic receptors in acetaminophen analgesia in humans and evaluate the possible drug interaction between $5-\mathrm{HT}_{3}$ blockers and acetaminophen, which are used in cancer patients together for vomiting and pain management, respectively. The first report showed blockage of the analgesic effect of acetaminophen ( $1 \mathrm{~g}$, oral) when administered after tropisetron (5 mg, i.v.) or granisetron (3 mg, i.v.) in healthy volunteers tested with electrically stimulated pain. ${ }^{35}$ The results of another study revealed that descending serotonergic inhibitory pathway stimulation by acetaminophen contributed to acetaminophen analgesia in healthy volunteers where central $5-\mathrm{HT}_{3}$ receptors were involved. ${ }^{36}$ These data were confirmed by a randomized, double-blind, and placebo-controlled study conducted in 16 healthy volunteers in which the combination of $1 \mathrm{~g}$ intravenous acetaminophen with $5 \mathrm{mg}$ of tropisetron exerted no analgesic action in electrically stimulated pain. In that study, tropisetron and acetaminophen alone both led to analgesic actions. ${ }^{37}$ The analgesic action of tropisetron administration alone was also confirmed by Tiippana et al. ${ }^{16}$ in healthy volunteers. Due to the fact that co-administration of acetaminophen with tropisetron in healthy volunteers did not lead to statistically significant changes in the blood levels of acetaminophen, 35,37 it has been claimed that the interaction between acetaminophen and tropisetron was pharmacodynamic. However, studies performed in post-operative patients revealed confusing results that were not totally parallel with the results of healthy volunteers. Ondansetron ( $4 \mathrm{mg}$ ) did not change the analgesic action of acetaminophen in women who underwent laparoscopic hysterectomy. ${ }^{38}$ In a study performed in 36 patients who underwent ear surgery, those receiving a combination of tropisetron and acetaminophen reported higher pain scores but the increase was not statistically significant. However, patients who received tropisetron and acetaminophen needed more rescue analgesic agent. ${ }^{39} \mathrm{~A}$ randomized, double-blinded study showed that ondansetron $(8 \mathrm{mg}$ ) reduced the analgesic effect of acetaminophen $(1 \mathrm{~g})$ in patients who had undergone abdominal hysterectomy; however, this reduction was in a short period of time. ${ }^{40}$

The results of those human studies indicate that there is a questionable interaction between acetaminophen analgesia and $5-\mathrm{HT}_{3}$ blockers due to some conflicting results. Those conflicting results, showing a lack of obvious interaction, were mainly related to post-operative pain conditions. ${ }^{38,39}$ However, in healthy volunteers, the interaction between acetaminophen and $5-\mathrm{HT}_{3}$ blockers (tropisetron and granisetron) seems more obvious and is likely to be a pharmacodynamic interaction. ${ }^{35-37}$ Apparently, studies with larger patient populations with different painful conditions are needed to clarify the interaction between $5-\mathrm{HT}_{3}$ blockers and acetaminophen in humans.

\section{Role of $5-\mathrm{HT}_{7}$ receptors}

$5-\mathrm{HT}_{7}$ receptors are $\mathrm{G}$ protein-coupled receptors linked with adenylyl cyclase and detected in the central nervous system regions that are involved in pain transmission, like the cerebral cortex, the thalamus, and the superficial lamina of the dorsal horn. ${ }^{41}$ Despite the fact that $5-\mathrm{HT}_{7}$ receptors are one of the serotonergic receptor subtypes that have been studied less compared to the other subtypes $\left(5-\mathrm{HT}_{1}, 5-\mathrm{HT}_{2}\right.$, and $5-\mathrm{HT}_{3}$ subtypes), ${ }^{41}$ some studies pointed out the contribution of these receptors to the antinociceptive action of acetaminophen in the last decade. Dogrul et al. ${ }^{12}$ used SB-269970 as a selective $5-\mathrm{HT}_{7}$ receptor antagonist to evaluate the role of these receptors in acetaminophen analgesia and administered intrathecally (10 $\mu g$ ) after the oral administration of $200-600 \mathrm{mg} / \mathrm{kg}$ acetaminophen in mice. Intrathecal administration of SB269970 blocked the antinociceptive action of acetaminophen in tail flick and hot plate tests. Similarly, intrathecal SB-269970 blocked the antihyperalgesic action of oral acetaminophen in a plantar-incision model. This study was the first to reveal the contribution of spinal $5-\mathrm{HT}_{7}$ receptors in the antinociceptive action of acetaminophen. A following study showed that an 
intrathecally administered lower dose of SB-269970 (3 $\mu \mathrm{g}$ ) was again successful in reversing the analgesic action of systemic acetaminophen in phase II of a formalin test in mice. This finding was important to confirm the contribution of spinal $5-\mathrm{HT}_{7}$ receptors in acetaminophen analgesia, but also revealed reduction in the reversing effect of SB-269970 administration on acetaminophen analgesia in mice lacking adenosine type1 receptors, which additionally indicated a strong interaction between the adenosinergic system and $5-\mathrm{HT}_{7}$ receptors in the analgesic action of acetaminophen. ${ }^{42}$

\section{The role of nitric oxide in acetaminophen analgesia}

$\mathrm{NO}$ is widely accepted as an important messenger molecule and neurotransmitter in the central nervous system that is involved in various physiological functions. ${ }^{43,44} \mathrm{NO}$ plays important roles in pain transmission, either inducing hyperexcitability leading to hyperalgesia or exerting antinociceptive actions. ${ }^{45-47}$

Björkman et al. ${ }^{48}$ in 1994 showed that suppression of $\mathrm{N}$-methyl$\mathrm{D}$-aspartate and substance P-induced pain related behaviors with acetaminophen administration was reversed by L-arginine administration to rats. Their study pointed out the involvement of neuronal NO systems in the analgesic action of acetaminophen. Additionally and in good accordance with that study, neuronal NO synthase was found to be involved in the analgesic effect of acetaminophen when acetaminophen was used in lower doses (especially with $100 \mathrm{mg} / \mathrm{kg}$, oral) in the RandallSelitto pain model, whereas both neuronal and inducible NO synthases were found to be involved in the analgesic action of acetaminophen in lower doses (especially 50 and $100 \mathrm{mg} /$ $\mathrm{kg}$, oral) in a writhing test. However, the involvement of NO systems was weak or nonexistent with the maximal doses of acetaminophen. ${ }^{49} \mathrm{It}$ has also been shown that acetaminophen inhibited induced NO synthesis in spinal cord tissue..$^{50}$ As a result, it can be concluded that NO systems are involved in acetaminophen analgesia and it is more likely that suppression of the central NO systems contributes to the central analgesic mechanisms of acetaminophen.

When focusing on the findings related to the interaction between acetaminophen and $\mathrm{NO}$ in the last decade, it might be appropriate not to underestimate the recent studies related to NO-acetaminophen (NCX-701). NO-acetaminophen is a novel compound with a combination of NO releasing moiety with acetaminophen. ${ }^{51}$ This novel compound has been shown to exert enhanced analgesic activity compared to the parent compound in non-inflamed, acetic-acid induced, and inflammatory pain models ${ }^{51-53}$ and was also analgesic in arthritis-related pain. ${ }^{54}$ Additionally, NO-acetaminophen had considerable antiinflammatory activity and less hepatotoxic potential compared to acetaminophen. ${ }^{51,52}$ The mechanism of action of NOacetaminophen has been suggested to be different from that of acetaminophen itself. It has been proposed that although NOacetaminophen and acetaminophen may share some common mechanisms like COX inhibition, the sustained release of low amounts of NO when combined with specific pharmacological actions of acetaminophen may add different but not clearly understood pharmacological properties. Inhibition of the wind- up phenomenon indicating a mechanism of action in the central nervous system level, more probably in the spinal cord, and reduction in the amounts of some cytokines in the peripheral tissues has been proposed. ${ }^{53,55}$

Additional to the above accumulated data related to the promising effects of $\mathrm{NO}$-acetaminophen, the antinociceptive effect of intravenously as well as intrathecally administered NO-acetaminophen has also been shown in a neuropathic pain model (partial ligation of the sciatic nerve) in rats, where acetaminophen alone was ineffective. In good accordance with the previous speculations, the spinal cord was claimed to be the anatomic region involved in this antihyperalgesic action of NO-acetaminophen. Addition of gabapentin to NOacetaminophen showed a synergistic effect. ${ }^{56}$ Similar to gabapentin, lowered doses of NO-acetaminophen also have been shown to enhance the analgesic effect of an $\alpha_{2}$-adrenergic receptor agonist, medetomidine, when combined with the sub-effective doses of NO-acetaminophen in a carrageenaninduced inflammatory model in rats. ${ }^{57}$ These two recent studies with NO-acetaminophen pointed out the beneficial effects of this novel acetaminophen compound in neuropathic and inflammatory pain conditions. Additionally, it is important to note that NO-acetaminophen was effective in conditions in which acetaminophen alone did not show analgesic action or NO-acetaminophen enhanced the analgesic potency of $\alpha_{2}$ adrenergic receptor agonist when acetaminophen alone did not. As a result, these studies showed that NO-acetaminophen can be an effective analgesic in neuropathic and inflammatory painful conditions and also can lead to synergistic actions when used in combination with gabapentin or $\alpha_{2}$-adrenergic receptor agonists in related painful conditions.

\section{CONCLUSION}

Findings in the last decade related to the contribution of the serotonergic system and NO in the analgesic effect of acetaminophen confirmed and expanded the involvement of these systems in acetaminophen analgesia. Due to the finding that direct binding of acetaminophen has not been shown with $5-\mathrm{HT}_{1}, 5-\mathrm{HT}_{2}$, or $5-\mathrm{HT}_{3}$ serotonergic receptor subtypes, ${ }^{58}$ interactions between these serotonergic receptors and acetaminophen are likely to be indirect. Recent studies confirmed bulbospinal serotonergic pathway involvement in acetaminophen analgesia and acetaminophen-induced serotonin increases in the central nervous system. The metabolite of acetaminophen, AM404, contributes to the analgesic effect of acetaminophen; however, the serotonergic receptor subtypes that contribute to the antinociceptive actions of acetaminophen and AM404 may be different. The involvement of $5-\mathrm{HT}_{1}$ receptors in acetaminophen analgesia is still not clear due to the conflicting results and requires to be evaluated with further studies. Despite the conflicting data, the contribution of $5-\mathrm{HT}_{2}$ receptors has been shown in acetaminophen analgesia (but not in AM404), and the localization is most likely to be the supra-spinal centers of the central nervous system. In animal studies, the blockage of acetaminophen analgesia with tropisetron is more obvious compared to ondansetron 
and granisetron. It seems that the speculation regarding the involvement of tropisetron-sensitive receptors instead of $5-\mathrm{HT}_{3}$ receptors in the analgesic action of acetaminophen is still valid and waiting to be confirmed and clarified with further studies. Recent studies showed the contribution of $5-\mathrm{HT}_{7}$ serotonergic receptor subtypes as well. Despite the fact that there are some conflicting results between the studies in volunteers and postoperative patients, an important number of human studies expanded the data regarding the contribution of serotonergic receptors. Although there were not many additional findings related to the contribution of NO systems in the antinociceptive action of acetaminophen, the latest findings expanded the beneficial analgesic effects of the NO releasing derivative of acetaminophen, NO-acetaminophen.

Conflict of Interest: No conflict of interest was declared by the authors.

\section{REFERENCES}

1. Botting R, Ayoub SS. COX-3 and the mechanism of action of acetaminophen/acetaminophen. Prostaglandins Leukot Essent Fatty Acids. 2005;72:85-87.

2. Graham GG, Scott KF. Mechanism of action of paracetamol. Am J Ther. 2005;12:46-55.

3. Anderson BJ. Paracetamol (Acetaminophen): mechanisms of action. Paediatr Anaesth. 2008;18:915-921.

4. Păunescu H, Coman OA, Coman L, Ghiţă I, Georgescu SR, Drăghia F, Fulga I. Cannabinoid system and cyclooxygenases inhibitors. J Med Life. 2011;4:11-20.

5. Ruggieri V, Vitale G, Pini LA, Sandrini M. Differential involvement of opioidergic and serotonergic systems in the antinociceptive activity of $\mathrm{N}$-arachidonoyl-phenolamine (AM404) in the rat: comparison with paracetamol. Naunyn Schmiedebergs Arch Pharmacol. 2008;377:219229.

6. Tariq SA, Khan H, Popalzai AJ, Niazi IU, Safiullah. Attenuation of erythrocytic acetyl cholinesterase by acetaminophen and chloroquine: evidence in an in vitro study. Pak J Pharm Sci. 2014;27:261-264.

7. Bhagyashree A, Manikkoth S, Sequeira M, Nayak R, Rao SN. Central dopaminergic system plays a role in the analgesic action of acetaminophen: Preclinical evidence. Indian J Pharmacol. 2017;49:2125.

8. Kerckhove N, Mallet C, François A, Boudes M, Chemin J, Voets T, Bourinet E, Alloui A, Eschalier A. Ca(v)3.2 calcium channels: the key protagonist in the supraspinal effect of paracetamol. Pain. 2014;155:764-772.

9. Tjølsen A, Lund A, Hole K. Antinociceptive effect of paracetamol in rats is partly dependent on spinal serotonergic systems. Eur J Pharmacol. 1991;193:193-201.

10. Pini LA, Sandrini M, Vitale G. The The antinociceptive action of paracetamol is associated with changes in the serotonergic system in the rat brain. Eur J Pharmacol. 1996;308:31-40.

11. Mallet C, Daulhac L, Bonnefont J, Ledent C, Etienne M, Chapuy E, Libert $F$, Eschalier A. Endocannabinoid and serotonergic systems are needed for acetaminophen-induced analgesia. Pain. 2008;139:190-200.

12. Dogrul A, Seyrek M, Akgul EO, Cayci T, Kahraman S, Bolay H. Systemic paracetamol-induced analgesic and antihyperalgesic effects through activation of descending serotonergic pathways involving spinal 5- $\mathrm{HT}_{\text {, }}$ receptors. Eur J Pharmacol. 2012;677:93-101.

13. Muchacki R, Szkilnik R, Malinowska-Borowska J, Żelazko A, Lewkowicz $Ł$, Nowak PG. Impairment in Pain Perception in Adult Rats Lesioned as Neonates with 5.7-Dihydroxytryptamine. Adv Clin Exp Med. 2015;24:419427.

14. Vijayakaran K, Kesavan M, Kannan K, Sankar P, Tandan SK, Sarkar SN. Arsenic decreases antinociceptive activity of acetaminophen: possible involvement of serotonergic and endocannabinoid receptors. Environ Toxicol Pharmacol. 2014;38:397-405.

15. Blecharz-Klin K, Piechal A, Pyrzanowska J, Joniec-Maciejak I, Kiliszek P. Widy-Tyszkiewicz E. Paracetamol--the outcome on neurotransmission and spatial learning in rats. Behav Brain Res. 2013;253:157-164.

16. Tiippana E, Hamunen K, Kontinen V, Kalso E. The effect of paracetamol and tropisetron on pain: experimental studies and a review of published data. Basic Clin Pharmacol Toxicol. 2013;112:124-131.

17. Högestätt ED, Jönsson BA, Ermund A, Andersson DA, Björk $H$, Alexander JP, Cravatt BF, Basbaum Al, Zygmunt PM. Conversion of acetaminophen to the bioactive $\mathrm{N}$-acylphenolamine AM404 via fatty acid amide hydrolase-dependent arachidonic acid conjugation in the nervous system. J Biol Chem. 2005;280:31405-31412.

18. De Petrocellis L, Bisogno T, Davis JB, Pertwee RG, Di Marzo V. Overlap between the ligand recognition properties of the anandamide transporter and the VR1 vanilloid receptor: inhibitors of anandamide uptake with negligible capsaicin-like activity. FEBS Lett. 2000;483:52-56.

19. Barrière DA, Mallet $C$, Blomgren $A$, Simonsen $C$, Daulhac $L$, Libert $F$, Chapuy E, Etienne M, Högestätt ED, Zygmunt PM, Eschalier A. Fatty acid amide hydrolase-dependent generation of antinociceptive drug metabolites acting on TRPV1 in the brain. PLoS One. 2013;8:e70690.

20. Tiger M, Varnäs K, Okubo Y, Lundberg J. The 5-HT(1B) receptor - a potential target for antidepressant treatment. Psychopharmacology (Berl). 2018;235:1317-1334.

21. Dreshfield LJ, Wong DT, Perry KW, Engleman EA. Enhancement of fluoxetine-dependent increase of extracellular serotonin (5-HT) levels by (-)-pindolol, an antagonist at 5-HT1A receptors. Neurochem Res. 1996;21:557-562.

22. Courade JP, Chassaing C, Bardin L, Alloui A, Eschalier A. 5-HT receptor subtypes involved in the spinal antinociceptive effect of acetaminophen in rats. Eur J Pharmacol. 2001;432:1-7.

23. Foong JP, Bornstein JC. 5-HT antagonists NAN-190 and SB 269970 block alpha2-adrenoceptors in the guinea pig. Neuroreport. 2009;20:325-330.

24. Roca-Vinardell A, Ortega-Alvaro A, Gibert-Rahola J, Micó JA. The role of $5-\mathrm{HT} 1 \mathrm{~A} / \mathrm{B}$ autoreceptors in the antinociceptive effect of systemic administration of acetaminophen. Anesthesiology. 2003;98:741-747.

25. Sandrini M, Pini LA, Vitale G. Differential involvement of central 5-HT1B and 5-HT3 receptor subtypes in the antinociceptive effect of acetaminophen. Inflamm Res. 2003;52:347-352.

26. Karandikar YS, Belsare P, Panditrao A. Effect of drugs modulating serotonergic system on the analgesic action of acetaminophen in mice. Indian J Pharmacol. 2016;48:281-285.

27. Srikiatkhachorn A, Tarasub N, Govitrapong P. Acetaminophen-induced antinociception via central 5-HT(2A) receptors. Neurochem Int. 1999;34:491-498.

28. Pelissier T, Alloui A, Caussade F, Dubray C, Cloarec A, Lavarenne J, Eschalier A. Paracetamol exerts a spinal antinociceptive effect involving 
an indirect interaction with 5-hydroxytryptamine3 receptors: in vivo and in vitro evidence. J Pharmacol Exp Ther. 1996;278:8-14.

29. Alloui A, Chassaing C, Schmidt J, Ardid D, Dubray C, Cloarec A, Eschalier A. Paracetamol exerts a spinal, tropisetron-reversible, antinociceptive effect in an inflammatory pain model in rats. Eur $\mathrm{J}$ Pharmacol. 2002;443:71-77.

30. Libert F, Bonnefont J, Bourinet E, Doucet E, Alloui A, Hamon M, Nargeot J, Eschalier A. Acetaminophen: a central analgesic drug that involves a spinal tropisetron-sensitive, non-5-HT(3) receptor-mediated effect. Mol Pharmacol. 2004;66:728-734.

31. Girard P, Pansart Y, Coppé MC, Niedergang B, Gillardin JM. Modulation of paracetamol and nefopam antinociception by serotonin 5-HT(3) receptor antagonists in mice. Pharmacology. 2009;83:243-246.

32. Gan TJ. Selective serotonin $5-\mathrm{HT} 3$ receptor antagonists for postoperative nausea and vomiting: are they all the same? CNS Drugs. 2005;19:225238.

33. Ho KY, Gan TJ. Pharmacology, pharmacogenetics, and clinical efficacy of 5-hydroxytryptamine type 3 receptor antagonists for postoperative nausea and vomiting. Curr Opin Anaesthesiol. 2006;19:606-611.

34. Macor JE, Gurley D, Lanthorn T, Loch J, Mack RA, Mullen G, Tran O, Wright N, Gordon JC. The 5-HT3 antagonist tropisetron (ICS 205-930) is a potent and selective alpha7 nicotinic receptor partial agonist. Bioorg Med Chem Lett. 2001;11:319-321.

35. Pickering G, Loriot MA, Libert F, Eschalier A, Beaune P, Dubray C. Analgesic effect of acetaminophen in humans: first evidence of a central serotonergic mechanism. Clin Pharmacol Ther. 2006;79:371-378.

36. Pickering G, Estève V, Loriot MA, Eschalier A, Dubray C. Acetaminophen reinforces descending inhibitory pain pathways. Clin Pharmacol Ther. 2008;84:47-51.

37. Bandschapp O, Filitz J, Urwyler A, Koppert W, Ruppen W. Tropisetron blocks analgesic action of acetaminophen: a human pain model study. Pain. 2011;152:1304-1310.

38. Jokela R, Ahonen J, Seitsonen E, Marjakangas P, Korttila K. The influence of ondansetron on the analgesic effect of acetaminophen after laparoscopic hysterectomy. Clin Pharmacol Ther. 2010;87:672-678.

39. Pickering G, Faure M, Commun F, de Boissy EC, Roche G, Mom T, Simen E, Dubray C, Eschalier A, Gilain L. Tropisetron and paracetamol association in post-operative patients. Fundam Clin Pharmacol. 2012;26:432-437.

40. Koyuncu O, Leung S, You J, Oksar M, Turhanoglu S, Akkurt C, Dolapcioglu $K$, Sahin H, Sessler DI, Turan A. The effect of ondansetron on analgesic efficacy of acetaminophen after hysterectomy: A randomized double blinded placebo controlled trial. J Clin Anesth. 2017;40:78-83.

41. Leopoldo M, Lacivita E, Berardi F, Perrone R, Hedlund PB. Serotonin 5-HT7 receptor agents: Structure-activity relationships and potential therapeutic applications in central nervous system disorders. Pharmacol Ther. 2011;129:120-148.

42. Liu J, Reid AR, Sawynok J. Antinociception by systemically-administered acetaminophen (acetaminophen) involves spinal serotonin 5-HT7 and adenosine $A 1$ receptors, as well as peripheral adenosine $A 1$ receptors. Neurosci Lett. 2013;536:64-68.
43. Dawson TM, Dawson VL, Snyder SH. A novel neuronal messenger molecule in brain: the free radical, nitric oxide. Ann Neurol. 1992;32:297311.

44. Džoljić E, Grbatinić I, Kostić V. Why is nitric oxide important for our brain? Funct Neurol. 2015;30:159-163.

45. Meller ST, Gebhart GF. Nitric oxide (NO) and nociceptive processing in the spinal cord. Pain. 1993;52:127-136.

46. Lothe A, Li P, Tong C, Yoon Y, Bouaziz H, Detweiler DJ, Eisenach JC. Spinal cholinergic alpha-2 adrenergic interactions in analgesia and hemodynamic control: role of muscarinic receptor subtypes and nitric oxide. J Pharmacol Exp Ther. 1994;270:1301-1306.

47. Millan MJ. The induction of pain: an integrative review. Prog Neurobiol. 1999;57:1-164.

48. Björkman R, Hallman KM, Hedner J, Hedner T, Henning M. Acetaminophen blocks spinal hyperalgesia induced by NMDA and substance P. Pain. 1994;57:259-264.

49. Bujalska M, Gumułka WS. Effect of cyclooxygenase and NO synthase inhibitors on antinociceptive action of acetaminophen. Pol J Pharmacol. 2001;53:341-350.

50. Godfrey L, Bailey I, Toms NJ, Clarke GD, Kitchen I, Hourani SM. Paracetamol inhibits nitric oxide synthesis in murine spinal cord slices. Eur J Pharmacol. 2007;562:68-71.

51. Moore PK, Marshall M. Nitric oxide releasing acetaminophen (nitroacetaminophen). Dig Liver Dis. 2003;35(Suppl 2):49-60.

52. al-Swayeh OA, Futter LE, Clifford RH, Moore PK. Nitroparacetamol exhibits anti-inflammatory and anti-nociceptive activity. Br J Pharmacol. 2000;130:1453-1456.

53. Romero-Sandoval EA, Mazario J, Howat D, Herrero JF. NCX-701 (nitroparacetamol) is an effective antinociceptive agent in rat withdrawal reflexes and wind-up. Br J Pharmacol. 2002;135:1556-1562.

54. Alfonso Romero-Sandoval E, Del Soldato P, Herrero JF. The effects of sham and full spinalization on the antinociceptive effects of NCX701 (nitroparacetamol) in monoarthritic rats. Neuropharmacology. 2003;45:412-419.

55. Romero-Sandoval EA, Curros-Criado MM, Gaitan G, Molina C, Herrero JF. Nitroacetaminophen (NCX-701) and pain: first in a series of novel analgesics. CNS Drug Rev. 2007;13:279-295.

56. Curros-Criado MM, Herrero JF. Antinociceptive effects of NCX-701 (nitro-paracetamol) in neuropathic rats: enhancement of antinociception by co-administration with gabapentin. Br J Pharmacol. 2009;158:601609.

57. Molina C, Herrero JF. Subeffective doses of nitroparacetamol (NCX701) enhance the antinociceptive activity of the $\alpha_{2}$-adrenoceptor agonist medetomidine. Pharmacol Biochem Behav. 2011;99:385-390.

58. Raffa RB, Codd EE. Lack of binding of acetaminophen to 5-HT receptor or uptake sites (or eleven other binding/uptake assays). Life Sci. 1996;59:37-40. 